\title{
Speed control of doubly star induction motor (DSIM) using direct field oriented control (DFOC) based on fuzzy logic controller (FLC)
}

\author{
Lallouani Hellali*, Saad Belhamdi \\ Electrical Engineering Laboratory, University of Mohamed Boudiaf- Msila, Algeria
}

Corresponding Author Email: alouani28@live.fr

https://doi.org/10.18280/ama_c.730402

Received: 23 December 2017

Accepted: 15 March 2018

\section{Keywords:}

doubly star induction motor, PMW, fuzzy

logic, direct field orient control, robustness

\begin{abstract}
The aim for this paper is a proportional and integral (PI) controller and fuzzy logic (FLC) controller devoted to improve the performance of Direct field orient control (DFOC) strategy of doubly star induction motor (DSIM) fed by two inverters. In addition, the paper describes a model of doubly star induction motor in $\mathrm{d}-\mathrm{q}$ reference frame theory and its computer simulation in MATLAB/SIMULINK®, fed by Pulse Width Modulation (PWM) inverter to be studied. The performance of the Direct Field orientated control with a PI and FLC is tested under different speed command and load disturbances. And also show a better robustness beside the parametric variations of the motor.
\end{abstract}

\section{INTRODUCTION}

Nowadays, many industry segments need doubly star induction motors are one of widely used motor. Due to their advantages in power segmentation, reliability, and minimized torque pulsations. Such segmented structures are very attractive for high-power applications since they allow the use of lower rating power electronic devices at a switching frequency higher than the one usually used in three-phase AC machine drives. This machine has been used required in many applications, such as pumps, fans, compressors, rolling mills, cement mills, mine hoists [1].

In recent years, the multiphase machines, five-phase and six-phase induction are the most considered in the literature. The present study is focused on the doubly star Induction motor. This type of machine is composed by two three-phase windings shifted by 30 degrees and a standard simple squirrelcage rotor [2].

In order to ensure an effective control of DSIM, several methods have been proposed [3]. An alternative solution is the use of Direct Rotor-Field-Oriented Control (DFOC) is modern technique for high-performance control of PWM inverter fed DSIM. To achieve a variable speed operation a power electronics inverter can be used. The Direct field oriented control theory is the base of a special control method for doubly star induction motor drives. With this theory doubly star induction motors can be controlled like a separately excited dc motor. This method enables the control of field and torque of the DSIM independently (decoupling) by manipulating the corresponding field oriented quantities [4-5, $11,14]$.

In the aim to improve the performance of the electrical drives based on traditional DFOC, fuzzy logic direct oriented control attracts more and more the attention of many scientists the configuration and design of the fuzzy Logic Controller for the direct field oriented based control of DSIM. The proposed fuzzy logic controller has been successfully simulated on a simulink model with the help of fuzzy logic toolbox. The performance of the FLC compared with the conventional PI controller. The proposed FLC is insensitive to torque and speed command variation changes and changes in parameter variations.

This paper is structured as follows: In Section 2 the model of the DSIM is presented, a suitable transformation matrix is used to develop a simple dynamic model. We will describe the Direct Field Oriented control by a fuzzy logic controller; the designed direct field oriented models are introduced and explained, In order to improve the static and dynamic control performance of the DSIM in section 3. Section 4 shows simulation results for a comparison between the performances of FLC speed controller of direct field oriented control DSIM with those obtained from conventional PI controller under various conditions operation (resistant torque, reference speed and parameter variations). The section 5 concludes this paper.

\section{MACHINE MODELING}

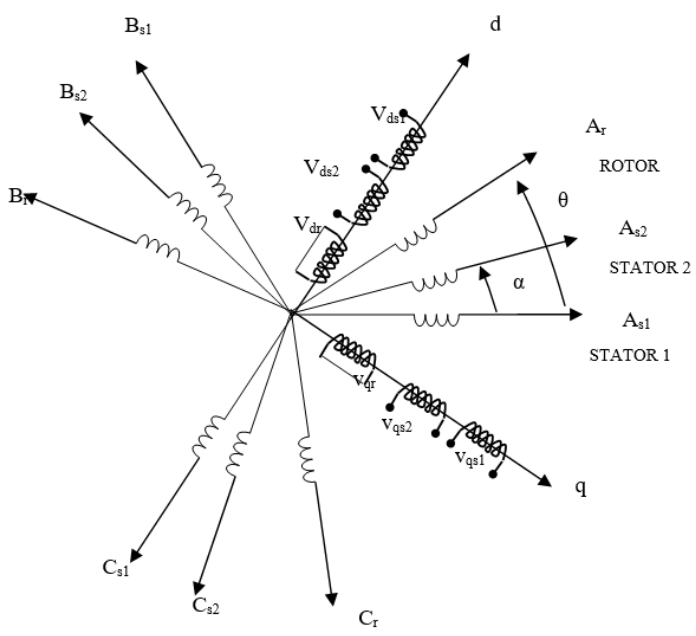

Figure 1. Doubly stator winding representation 
The doubly stator induction machine represented by two stators windings: $A_{\mathrm{s} 1}, \mathrm{~B}_{\mathrm{s} 1}, \mathrm{C}_{\mathrm{s} 1}$ and $\mathrm{A}_{\mathrm{s} 2}, \mathrm{~B}_{\mathrm{s} 2}, \mathrm{C}_{\mathrm{s} 2}$ which are displaced by $\alpha=\pi / 6$ electrical angle .and the rotor windings $\left(\mathrm{A}_{\mathrm{r}}\right.$, $\mathrm{B}_{\mathrm{r}}, \mathrm{C}_{\mathrm{r}}$ ) are sinusoidal distributed and have axes that are displaced apart by $2 \pi / 3$ [6].

The usual assumptions are adopted [7]:

Motor windings are sinusoidal distributed, and the saturation of magnetic circuit is neglected, and the two stars have same parameters, and the flux path is linear.

The windings of the DSIM are shown in Figure. 1

The voltage equations for stator and rotor circuits for model of the DSIM motor have the following matrix form [8]:

$\left[V_{\mathrm{s} 1, \mathrm{abc}}\right]=\left[R_{\mathrm{s} 1}\right]\left[i_{\mathrm{s} 1, \mathrm{abc}}\right]+\frac{d}{\mathrm{dt}}\left[\Phi_{\mathrm{s} 1, \mathrm{abc}}\right]\left[V_{\mathrm{s} 2, \mathrm{abc}}\right]=$

$\left[R_{\mathrm{s} 2}\right]\left[i_{\mathrm{s} 2, \mathrm{abc}}\right]+\frac{d}{\mathrm{dt}}\left[\Phi_{\mathrm{s} 2, \mathrm{abc}}\right] 0=\left[R_{r}\right]\left[i_{\mathrm{r}, \mathrm{abc}}\right]+\frac{d}{\mathrm{dt}}\left[\Phi_{\mathrm{r}, \mathrm{abc}}\right]$

With

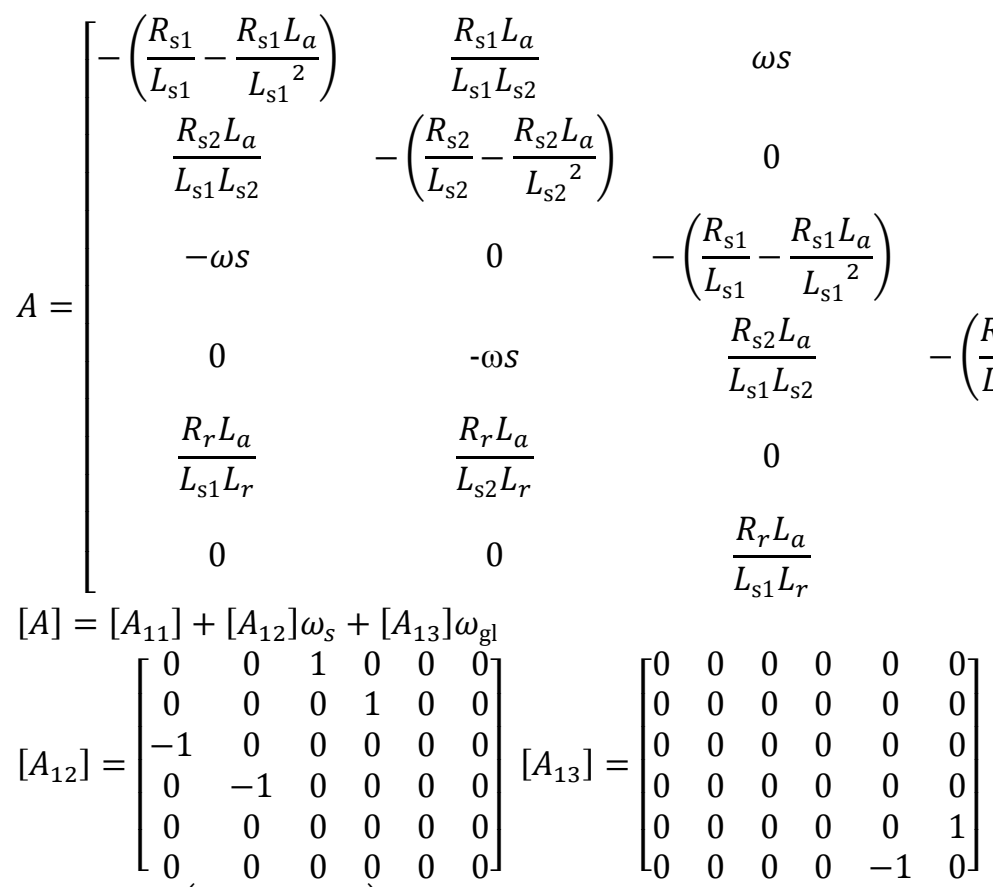

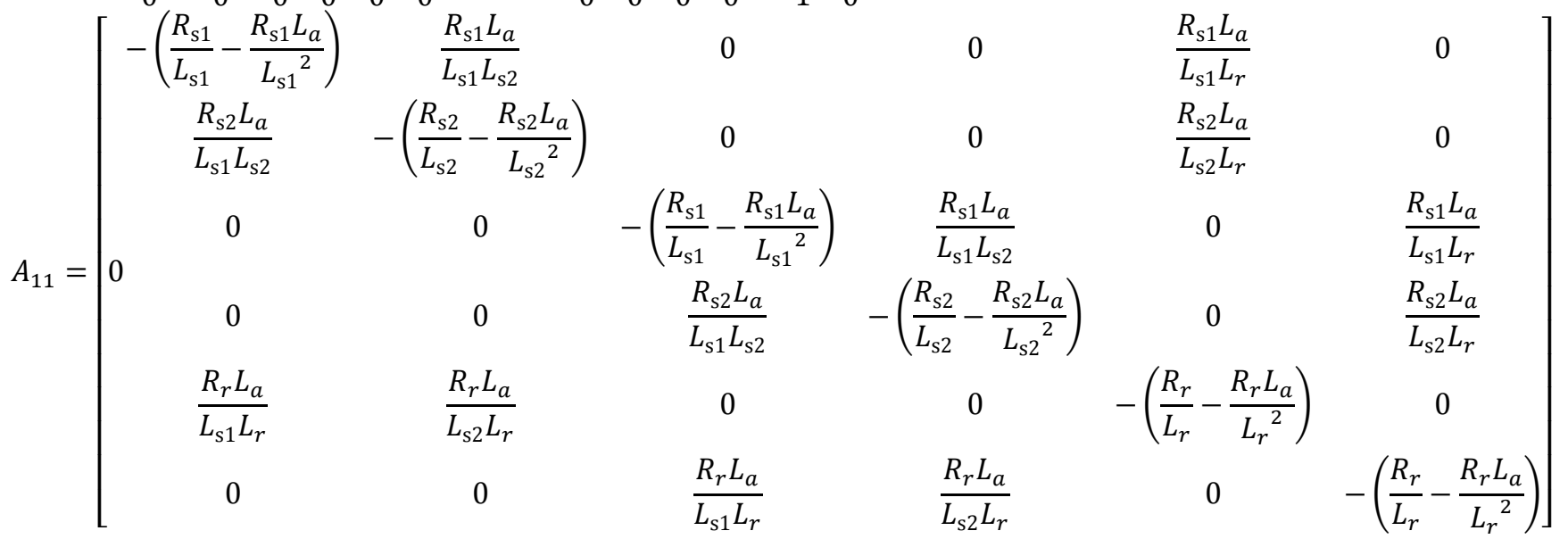

The relation flux $\left(\Phi_{\mathrm{s} 1 \mathrm{~d}}, \Phi_{\mathrm{s} 2 \mathrm{~d}}, \Phi_{\mathrm{s} 1 \mathrm{q}}, \Phi_{\mathrm{s} 2 \mathrm{q}}, \Phi_{\mathrm{rd}}\right.$, and $\left.\Phi_{\mathrm{rq}}\right)$ and current $\left(i_{\mathrm{s} 1 \mathrm{~d}}, i_{\mathrm{s} 2 \mathrm{~d}}, i_{\mathrm{s} 1 \mathrm{q}}, i_{\mathrm{s} 2 \mathrm{q}}, i_{\mathrm{rd}}\right.$ and $\left.i_{\mathrm{rq}}\right)$ are [9]. $X=[H] I$
$V_{\mathrm{s} 1, \mathrm{abc}}, V_{\mathrm{s} 2, \mathrm{abc}}:$ Stator voltages.

$i_{\mathrm{s} 1, \mathrm{abc}}, i_{\mathrm{s} 2, \mathrm{abc}}, i_{\mathrm{r}, \mathrm{abc}}:$ Stator and rotor currents.

$\Phi_{\mathrm{s} 1, \mathrm{abc}}, \Phi_{\mathrm{s} 2 \mathrm{abc}}, \Phi_{\mathrm{r}, \mathrm{abc}}$ : Stator and rotor flux.

$\left[R_{\mathrm{s} 1}\right],\left[R_{\mathrm{s} 2}\right],\left[R_{r}\right]$ : Resistance matrices stator and rotor.

In order to ensure the control, the DSIM model expressed in terms of d-and q-axes should be presented in state space frame [9]:

$$
\dot{X}=A X+B U
$$



where:

$$
\begin{aligned}
& U=\left[\begin{array}{lllll}
V_{\mathrm{s} 1 \mathrm{~d}} V_{\mathrm{s} 2 \mathrm{~d}} & V_{\mathrm{s} 1 \mathrm{q}} & V_{\mathrm{s} 2 \mathrm{q}} & 0 & 0
\end{array}\right]^{T} \\
& I=\left[\begin{array}{lllll}
i_{\mathrm{s} 1 \mathrm{~d}} i_{\mathrm{s} 2 \mathrm{~d}} & i_{\mathrm{s} 1 \mathrm{q}} & i_{\mathrm{s} 2 \mathrm{q}} & i_{\mathrm{rd}} & i_{\mathrm{rq}}
\end{array}\right]^{T}
\end{aligned}
$$

$V_{\mathrm{s} 1, \mathrm{dq}}, V_{\mathrm{s} 2, \mathrm{dq}}$ : Stator voltages dq components.

$i_{\mathrm{s} 1, \mathrm{dq}}, i_{\mathrm{s} 2, \mathrm{dq}}, i_{\mathrm{r}, \mathrm{dq}}:$ Stator and Rotor currents dq components.

$\Phi_{\mathrm{s} 1, \mathrm{dq}}, \Phi_{\mathrm{s} 2, \mathrm{dq}}, \Phi_{\mathrm{r}, \mathrm{dq}}$ : Stator and Rotor flux dq components.

0

$\omega S$

0

$\frac{R_{\mathrm{s} 1} L_{a}}{L_{\mathrm{s} 1} L_{\mathrm{s} 2}}$

0

$\frac{R_{\mathrm{s} 1} L_{a}}{L_{\mathrm{s} 1} L_{r}}$

0

$\frac{R_{\mathrm{s} 2} L_{a}}{L_{\mathrm{s} 2} L_{r}}$

0

$-\left(\frac{R_{r}}{L_{r}}-\frac{R_{r} L_{a}}{L_{r}^{2}}\right)$

$\omega_{\mathrm{gl}}$

$\frac{R_{r} L_{a}}{L_{\mathrm{s} 2} L_{r}}$

$-\omega_{\mathrm{gl}}$

$\left.-\left(\frac{R_{r}}{L_{r}}-\frac{R_{r} L_{a}}{L_{r}^{2}}\right)\right]$

$$
\begin{aligned}
& \frac{R_{\mathrm{s} 1} L_{a}}{L_{\mathrm{s} 1} L_{r}} \\
& \frac{R_{\mathrm{s} 2} L_{a}}{L_{\mathrm{s} 2} L_{r}}
\end{aligned}
$$


$[H]=\left[\begin{array}{cccccc}L_{\mathrm{s} 1}+L_{m} & L_{m} & 0 & 0 & L_{m} & 0 \\ L_{m} & L_{\mathrm{s} 2}+L_{m} & 0 & 0 & L_{m} & 0 \\ 0 & 0 & L_{\mathrm{s} 1}+L_{m} & L_{m} & 0 & L_{m} \\ 0 & 0 & L_{m} & L_{\mathrm{s} 2}+L_{m} & 0 & L_{m} \\ L_{m} & L_{m} & 0 & 0 & L_{r}+L_{m} & 0 \\ 0 & 0 & L_{m} & L_{m} & 0 & L_{r}+L_{m}\end{array}\right]$

where:

Lm: Cyclic mutual inductance between stator 1, stator 2 and rotor.

$\mathrm{L}_{\mathrm{s} 1, \mathrm{~s} 2, \mathrm{r} \text { : }}$ the inductance of a stator 1 , stator 2 and rotor respectively.

$\mathrm{L}_{\mathrm{s} 1}+\mathrm{L}_{\mathrm{m}}, \mathrm{L}_{\mathrm{s} 2}+\mathrm{L}_{\mathrm{m}}, \mathrm{L}_{\mathrm{r}}+\mathrm{L}_{\mathrm{m}}$ : the total inductance of a stator 1, stator 2 and rotor respectively.

Where definitions are given in (3), (4). The electromagnetic torque and the mechanical equations can be written as:

$C_{e m}=p \frac{L_{m}}{L_{m}+L_{r}}\left(\Phi_{\mathrm{rd}}\left(i_{\mathrm{s} 1 \mathrm{q}}+\mathrm{i}_{\mathrm{s} 2 \mathrm{q}}\right)-\Phi_{\mathrm{rq}}\left(i_{\mathrm{s} 1 \mathrm{~d}}+\mathrm{i}_{\mathrm{s} 2 \mathrm{~d}}\right)\right)$

$J \frac{d \Omega}{\mathrm{dt}}=C_{e m}-C_{r}-K_{f} \Omega$

\section{FIELD ORIENTED CONTROL}

The field oriented control technique relies on decoupling the machine torque and flux control [5]. We can obtain the DC machine like performance in holding a fixed and orthogonal orientation between the fields and armature fields in an $\mathrm{AC}$ machine by orienting the stator current with respect to rotor flux so as to attain independently controlled flux and torque.

There are essentially two general methods of vector control.

\subsection{Indirect Field Oriented Control (IFOC)}

In this method the angle is obtained by using rotor position measurement and machine parameter's estimation [10].

\subsection{Direct Field Oriented Control (DFOC)}

In direct FOC the rotor angle or control vector is obtained by the terminal voltages and currents directly by using flux estimators [12,18].

By applying this principle of field oriented $\operatorname{control}\left(\Phi_{\mathrm{rd}}=\right.$ $\Phi_{r}{ }^{*}$ to equations (1) (2) and (3), the final expression of the component references of slip speed $\omega_{\text {sr }}$ and the electromagnetic torque can be expressed as:

$\omega_{\mathrm{sr}}^{*}=\frac{R_{r} L_{m}}{\left(L_{m}+L_{r}\right) \Phi_{r}{ }^{*}}\left(i_{\mathrm{s} 1 \mathrm{q}}+i_{\mathrm{s} 2 \mathrm{q}}\right)$

$C_{e m}^{*}=\left(\frac{\mathrm{p} \mathrm{L}_{m} \Phi_{r}^{*}}{L_{m}+L_{r}}\right)\left(i_{\mathrm{s} 1 \mathrm{q}}+i_{\mathrm{s} 2 \mathrm{q}}\right)$

The relation voltage references $\left(V_{\mathrm{s} 1 \mathrm{~d}}{ }^{*}, V_{\mathrm{s} 1 \mathrm{q}}{ }^{*}, V_{\mathrm{s} 2 \mathrm{~d}}{ }^{*}\right.$ and $\left.V_{\mathrm{s} 2 \mathrm{q}}{ }^{*}\right)$ and currents stator components are:

$\left\{\begin{array}{l}V_{\mathrm{s} 1 \mathrm{~d}}{ }^{*}=\mathrm{R}_{\mathrm{s} 1} \mathrm{i}_{\mathrm{s} 1 \mathrm{~d}}+\mathrm{L}_{\mathrm{s} 1} \frac{\mathrm{d}}{\mathrm{dt}} \mathrm{i}_{\mathrm{s} 1 \mathrm{~d}}-\omega_{\mathrm{s}}{ }^{*}\left(\mathrm{~L}_{\mathrm{s} 1} \mathrm{i}_{\mathrm{s} 1 \mathrm{~d}}+\mathrm{T}_{\mathrm{r}} \omega_{\mathrm{sr}}{ }^{*} \Phi_{\mathrm{r}}{ }^{*}\right) \\ V_{\mathrm{s} 2 \mathrm{~d}}{ }^{*}=\mathrm{R}_{\mathrm{s} 2} \mathrm{i}_{\mathrm{s} 2 \mathrm{~d}}+\mathrm{L}_{\mathrm{s} 2} \frac{\mathrm{d}}{\mathrm{dt}} \mathrm{i}_{\mathrm{s} 2 \mathrm{~d}}-\omega_{\mathrm{s}}{ }^{*}\left(\mathrm{~L}_{\mathrm{s} 2} \mathrm{i}_{\mathrm{s} 2 \mathrm{~d}}+\mathrm{T}_{\mathrm{r}} \omega_{\mathrm{sr}}{ }^{*} \Phi_{\mathrm{r}}{ }^{*}\right) \\ V_{\mathrm{s} 1 \mathrm{q}}{ }^{*}=\mathrm{R}_{\mathrm{s} 1} \mathrm{i}_{\mathrm{s} 1 \mathrm{q}}+\mathrm{L}_{\mathrm{s} 1} \frac{\mathrm{d}}{\mathrm{dt}} \mathrm{i}_{\mathrm{s} 1 \mathrm{q}}+\omega_{\mathrm{s}}{ }^{*}\left(\mathrm{~L}_{\mathrm{s} 1} \mathrm{i}_{\mathrm{s} 1 \mathrm{~d}}+\Phi_{\mathrm{r}}{ }^{*}\right) \\ V_{\mathrm{s} 2 \mathrm{q}}{ }^{*}=\mathrm{R}_{\mathrm{s} 2} \mathrm{i}_{\mathrm{s} 2 \mathrm{q}}+\mathrm{L}_{\mathrm{s} 2} \frac{\mathrm{d}}{\mathrm{dt}} \mathrm{i}_{\mathrm{s} 2 \mathrm{q}}+\omega_{\mathrm{s}}{ }^{*}\left(\mathrm{~L}_{\mathrm{s} 2} \mathrm{i}_{\mathrm{s} 2 \mathrm{q}}+\Phi_{\mathrm{r}}{ }^{*}\right)\end{array}\right.$

where $T_{r}=\frac{L_{r}}{R_{r}}$

This expression of the torque clearly shows the dependence between the quadrature stator currents and the reference flux, because of this, a necessary to decouple torque and flux control of this machine by introducing new variables:

$\left\{\begin{array}{l}V_{\mathrm{s} 1 \mathrm{~d}}=\mathrm{R}_{\mathrm{s} 1} \mathrm{i}_{\mathrm{s} 1 \mathrm{~d}}+\mathrm{L}_{\mathrm{s} 1} \frac{\mathrm{d}}{\mathrm{dt}} \mathrm{i}_{\mathrm{s} 1 \mathrm{~d}} \\ V_{\mathrm{s} 2 \mathrm{~d}}=\mathrm{R}_{\mathrm{s} 2} \mathrm{i}_{\mathrm{s} 2 \mathrm{~d}}+\mathrm{L}_{\mathrm{s} 2} \frac{\mathrm{d}}{\mathrm{dt}} \mathrm{i}_{\mathrm{s} 2 \mathrm{~d}} \\ V_{\mathrm{s} 1 \mathrm{q}}=\mathrm{R}_{\mathrm{s} 1} \mathrm{i}_{\mathrm{s} 1 \mathrm{q}}+\mathrm{L}_{\mathrm{s} 1} \frac{\mathrm{d}}{\mathrm{dt}} \mathrm{i}_{\mathrm{s} 1 \mathrm{q}} \\ V_{\mathrm{s} 2 \mathrm{q}}=\mathrm{R}_{\mathrm{s} 2} \mathrm{i}_{\mathrm{s} 2 \mathrm{q}}+\mathrm{L}_{\mathrm{s} 2} \frac{\mathrm{d}}{\mathrm{dt}} \mathrm{i}_{\mathrm{s} 2 \mathrm{q}}\end{array}\right.$

The equation system $(8)$ shows that stator voltages $\left(V_{\text {sld }}\right.$, $\left.V_{\mathrm{s} 2 \mathrm{~d}}, V_{\mathrm{slq}}, V_{\mathrm{s} 2 \mathrm{q}}\right)$ are directly related to stator currents $\left(\mathrm{i}_{\mathrm{s} 1 \mathrm{~d}}, \mathrm{i}_{\mathrm{s} 2 \mathrm{~d}}\right.$, $\left.i_{s 1 q}, i_{s 2 q}\right)$. To compensate for the error introduced during decoupling, the reference stator voltages $\left(V_{\mathrm{sld}}{ }^{*}, V_{\mathrm{s} 2 \mathrm{~d}}{ }^{*}, V_{\mathrm{slq}}{ }^{*}\right.$, $\left.V_{\mathrm{s} 2 \mathrm{q}}{ }^{*}\right)$ are given by $[13,17]$ :

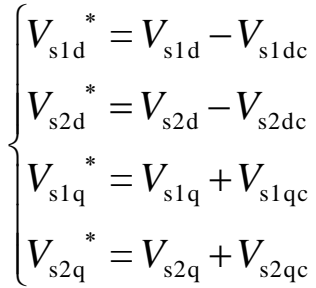

With

$\left\{\begin{array}{l}V_{\mathrm{s} 1 \mathrm{dc}}=\omega_{\mathrm{s}}{ }^{*}\left(\mathrm{~L}_{\mathrm{s} 1} \mathrm{i}_{\mathrm{s} 1 \mathrm{~d}}+\mathrm{T}_{\mathrm{r}} \omega_{\mathrm{sr}}{ }^{*} \Phi_{\mathrm{r}}{ }^{*}\right) \\ V_{\mathrm{s} 2 \mathrm{dc}}=\omega_{\mathrm{s}}{ }^{*}\left(\mathrm{~L}_{\mathrm{s} 2} \mathrm{i}_{\mathrm{s} 2 \mathrm{~d}}+\mathrm{T}_{\mathrm{r}} \omega_{\mathrm{sr}}{ }^{*} \Phi_{\mathrm{r}}{ }^{*}\right) \\ V_{\mathrm{s} 1 \mathrm{qc}}=\omega_{\mathrm{s}}{ }^{*}\left(\mathrm{~L}_{\mathrm{s} 1} i_{\mathrm{s} 1 \mathrm{~d}}+\Phi_{\mathrm{r}}{ }^{*}\right) \\ V_{\mathrm{s} 2 \mathrm{qc}}=\omega_{\mathrm{s}}{ }^{*}\left(\mathrm{~L}_{\left.\mathrm{s} 2 \mathrm{i}_{\mathrm{s} 2 \mathrm{q}}+\Phi_{\mathrm{r}}{ }^{*}\right)}\right.\end{array}\right.$

For a perfect decoupling, we add stator currents regulation loops ( $\left.i_{\text {sld }}, i_{s 2 d}, i_{s 1 q}, i_{s 2 q}\right)$.and we obtain at their output stator voltages ( $\left.V_{\mathrm{sld}}, V_{\mathrm{s} 2 \mathrm{~d}}, V_{\mathrm{s} 1 \mathrm{q}}, V_{\mathrm{s} 2 \mathrm{q}}\right)$. The goal of the regulation is to assure a best robustness to intern or extern perturbations. In this work, proportional integral and fuzzy regulators have been used. 


\subsubsection{Rotor Flux Estimation}

In direct vector control method, it is necessary to estimate the rotor flux components $\Phi_{\text {rd }}$ and $\Phi_{\text {rq }}$ the components of rotor flux can be estimated by:

$\frac{d}{\mathrm{dt}} \Phi_{\text {rdest }}=\left(\frac{R_{r} L_{m}}{L_{m}+L}\right)\left(i_{\mathrm{s} 1 \mathrm{~d}}+i_{\mathrm{s} 2 \mathrm{~d}}\right)+\omega_{\mathrm{sr}}{ }^{*} \Phi_{\text {rqest }}-$

$\frac{R_{r} L_{m}}{L_{m}+L} \Phi_{\text {rdest }} \frac{d}{\mathrm{dt}} \Phi_{\text {rqest }}=\left(\frac{R_{r} L_{m}}{L_{m}+L}\right)\left(i_{\mathrm{s} 1 \mathrm{q}}+i_{\mathrm{s} 2 \mathrm{q}}\right)-\omega_{\mathrm{sr}}{ }^{*} \Phi_{\text {rdest }}-$

$\frac{R_{r} L_{m}}{L_{m}+L} \Phi_{\text {rqest }}$

The rotor flux amplitude is given by:

$\left|\Phi_{\text {rest }}\right|=\sqrt{\Phi_{\text {rdest }}^{2}+\Phi_{\text {rqest }}^{2}}$

\subsubsection{Principe of a fuzzy controller}

The control by fuzzy logic permits to obtain a law of drive, often very effective, without having a precise model of the process, from a linguistic description of the behavior of the system. Its approach is different the one of the automatic classic, in the sense that it does not treat mathematical relations well defined, but it exploits the knowledge of an expert. These are expressed by means of conduct rules based on a symbolic vocabulary and manipulate inferences with several rules using the fuzzy operators AND, OR, THEN, applied to linguistic variables. [15].

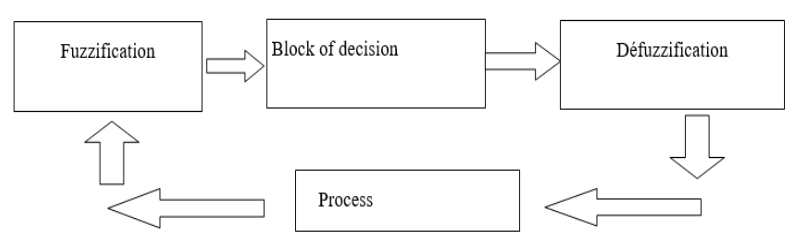

Figure 2. Structure interns of a system Fuzzy

Wo inputs of speed fuzzy controller are chosen, the speed error (e) and its variation $\Delta \mathrm{e}$ :

$e=\omega_{r}^{*}-\omega_{r}$
$\Delta e(k)=e(k)-e(k-1)$

Figure 3 in which the linguistic variables are represented by NB (Negative Big), NM (Negative Medium), NS (Negative Small), Z (Zero), PS (Positive Small), PM (Positive Medium) and PB (Positive Big).

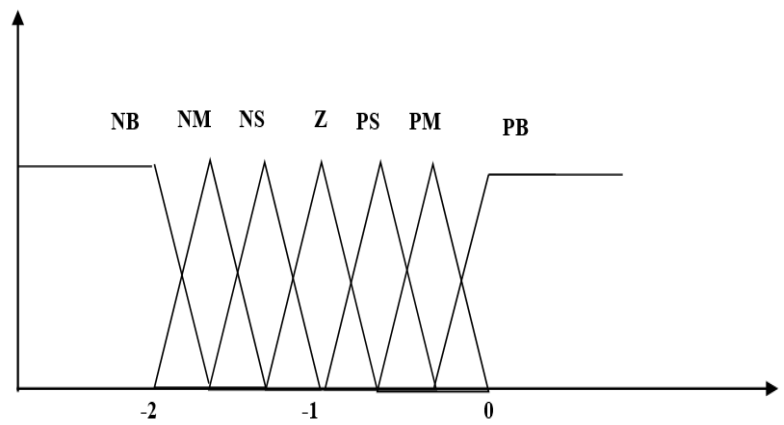

Figure 3. Fuzzification with seven memberships

Table 1 shows one of possible control rules based on seven membership functions [16].

Table 1. The fuzzy control rule bases

\begin{tabular}{llllllll}
\hline$e$ & $\mathrm{NB}$ & $\mathrm{NM}$ & $\mathrm{NS}$ & $\mathrm{ZE}$ & $\mathrm{PS}$ & $\mathrm{PM}$ & $\mathrm{PB}$ \\
$\Delta e$ & & & & & & & \\
\hline $\mathrm{NB}$ & $\mathrm{NB}$ & $\mathrm{NB}$ & $\mathrm{NB}$ & $\mathrm{NB}$ & $\mathrm{NM}$ & $\mathrm{NS}$ & $\mathrm{ZE}$ \\
$\mathrm{NM}$ & $\mathrm{NB}$ & $\mathrm{NB}$ & $\mathrm{NB}$ & $\mathrm{NM}$ & $\mathrm{NS}$ & $\mathrm{ZE}$ & $\mathrm{PS}$ \\
$\mathrm{NS}$ & $\mathrm{NB}$ & $\mathrm{NB}$ & $\mathrm{NM}$ & $\mathrm{NS}$ & $\mathrm{ZE}$ & $\mathrm{PS}$ & $\mathrm{PM}$ \\
$\mathrm{ZE}$ & $\mathrm{NB}$ & $\mathrm{NM}$ & $\mathrm{NS}$ & $\mathrm{ZE}$ & $\mathrm{PS}$ & $\mathrm{PM}$ & $\mathrm{PB}$ \\
$\mathrm{PS}$ & $\mathrm{NM}$ & $\mathrm{NS}$ & $\mathrm{ZE}$ & $\mathrm{PS}$ & $\mathrm{PM}$ & $\mathrm{PB}$ & $\mathrm{PB}$ \\
$\mathrm{PM}$ & $\mathrm{NS}$ & $\mathrm{ZE}$ & $\mathrm{PS}$ & $\mathrm{PM}$ & $\mathrm{PB}$ & $\mathrm{PB}$ & $\mathrm{PB}$ \\
$\mathrm{PB}$ & $\mathrm{ZE}$ & $\mathrm{PS}$ & $\mathrm{PM}$ & $\mathrm{PB}$ & $\mathrm{PB}$ & $\mathrm{PB}$ & $\mathrm{PB}$ \\
\hline
\end{tabular}

The block diagram of the fuzzy logic for the DFOC approach of the DSIM is shown in figure 4.

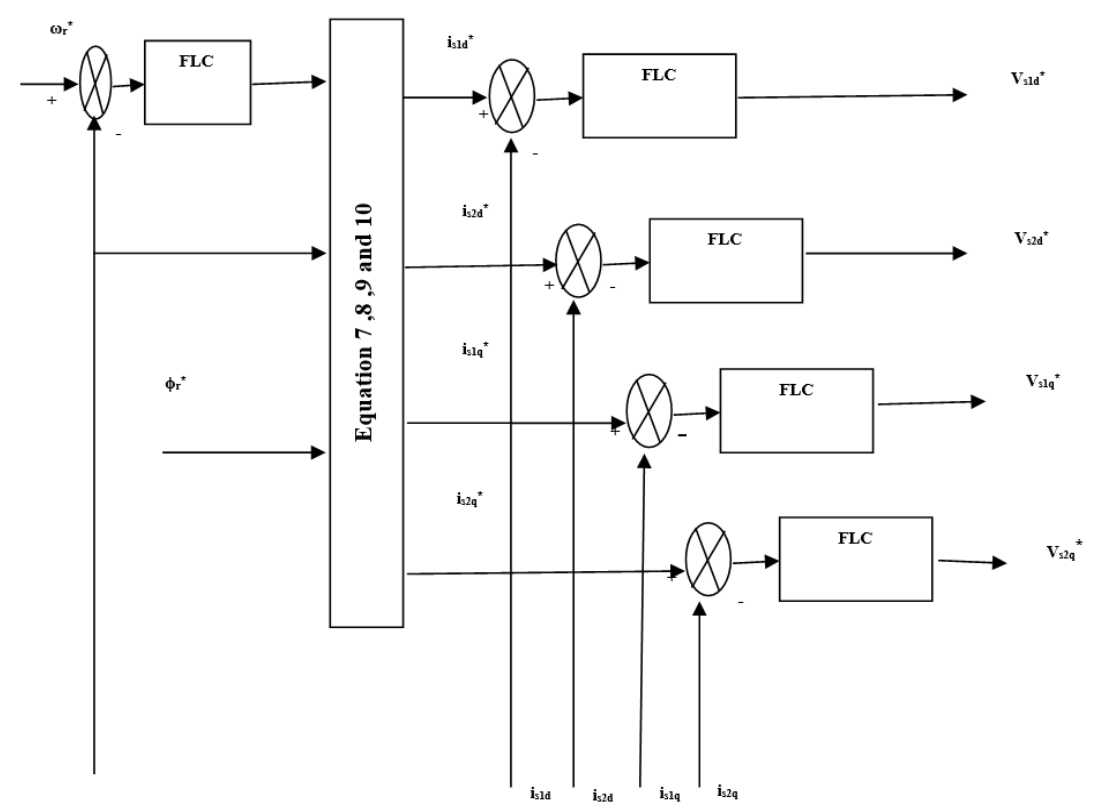

Figure 4. Block diagram of the fuzzy logic PI controller for DFOC approach of the DSIM 
The general structure of the doubly stator induction motor with direct field oriented control using a two inverter in each star is represented by figure 5 .

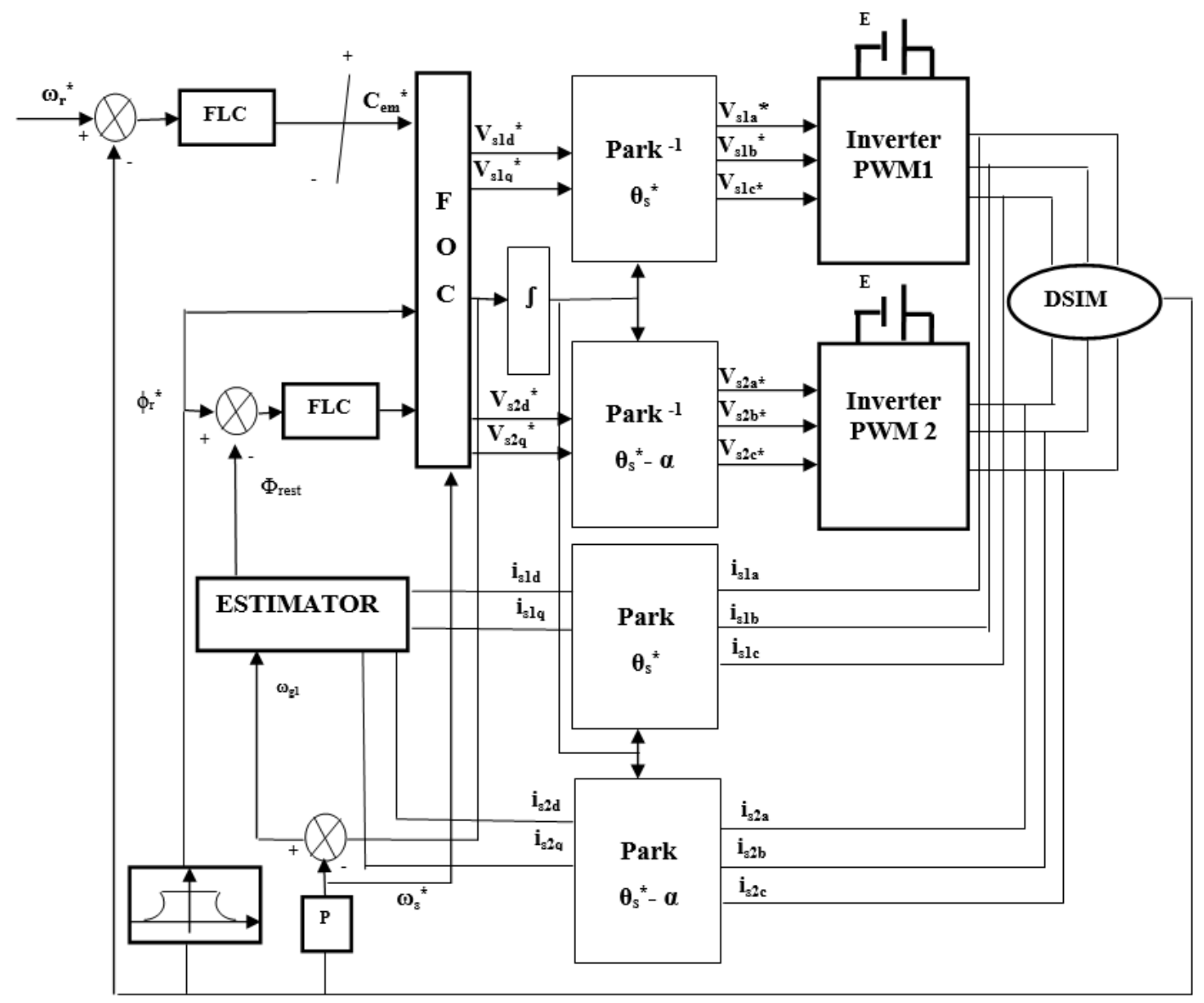

Figure 5. Structure of speed ordering for the DSIM

\section{RESULTS AND DISCUSSION}

The simulation is done using MATLAB and results are presented here, the motor used in the simulation study is a $4.5 \mathrm{Kw}$ cage rotor, $220 \mathrm{~V}, 50 \mathrm{HZ}$. The parameters of the DSIM

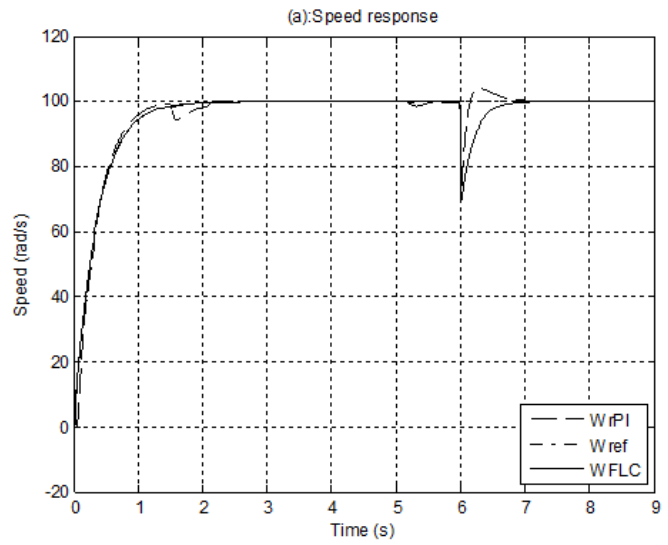

are summarized in Appendix. The simulation work is carried on two tests of Robustness studies:

In first test the Torque variation with the sign of resistant torque $\left(\mathrm{C}_{\mathrm{r}}=10 \mathrm{~N} . \mathrm{m}\right)$ during the interval ]2-5] sec, and the DSIM runs with speed values (100 rad/s during] 0-6] sec, 30rad/s during] 6-9] sec).

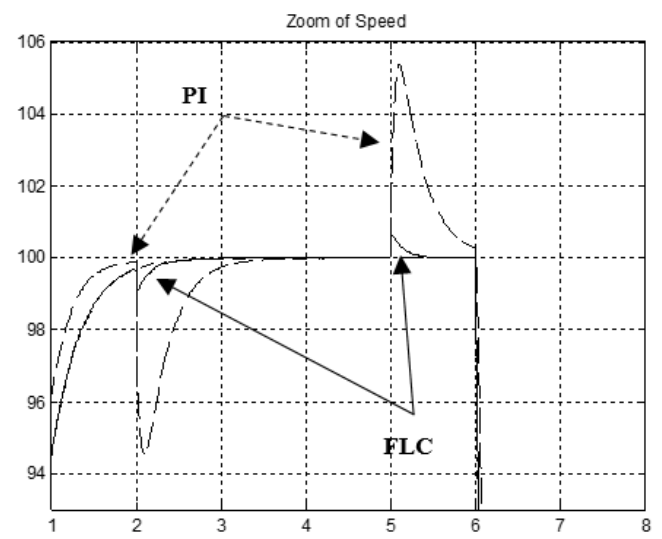



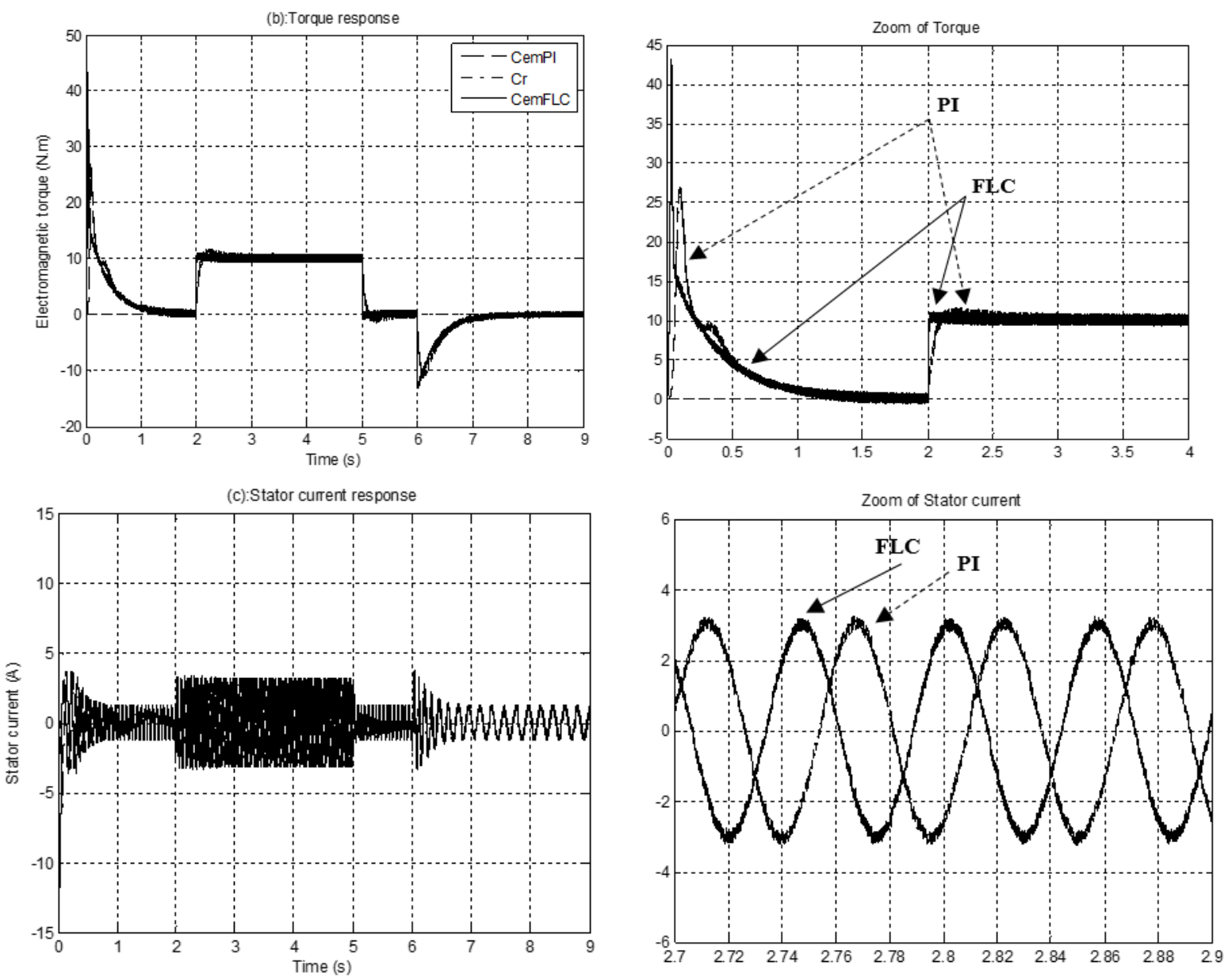

Figure 6. Speed, torque and current stator characteristic of an (DFOC) with PI and FLC

Controllers, at changes in load torque and speed.
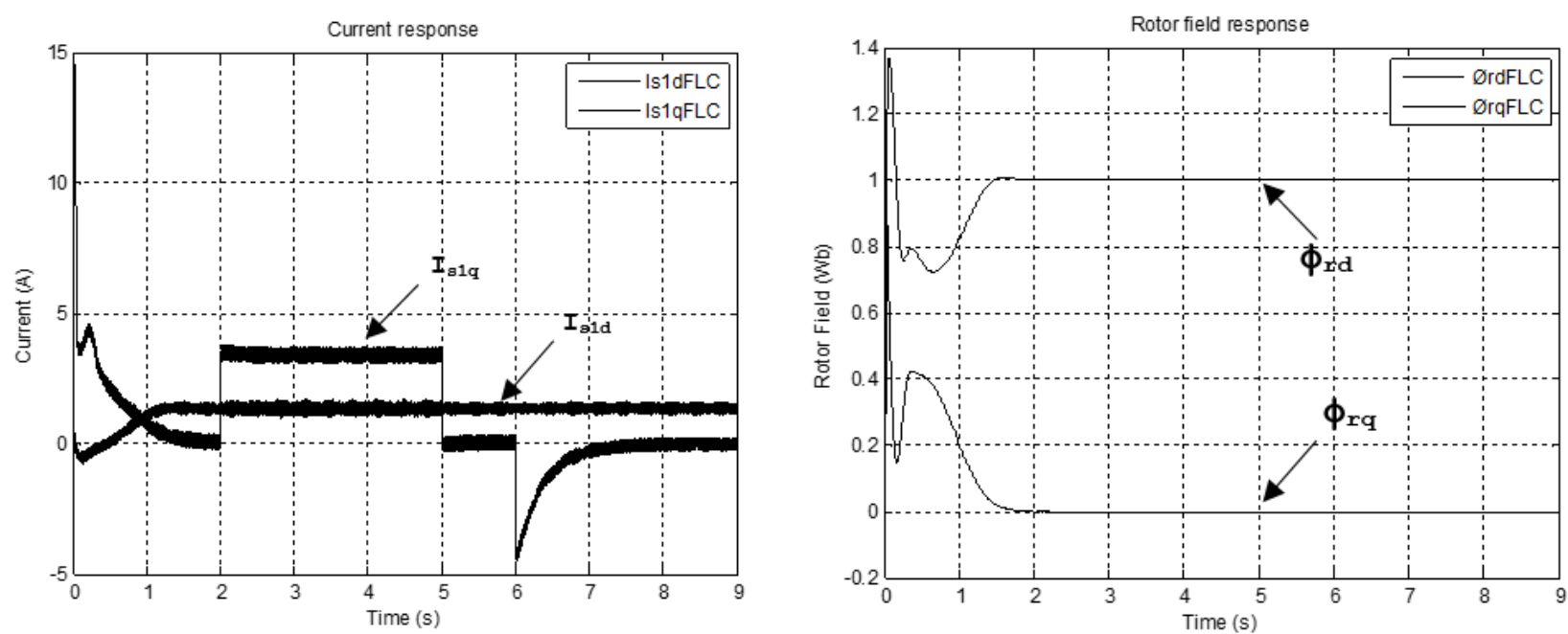

Figure 7. Decoupling and rotor field orientation

The next tests sets the parameters variations of DSIM with the two controllers (PI and FLC), the Rotor resistance changed
$\left(\mathrm{R}_{\mathrm{r} 1}=1.5 * \mathrm{R}_{\mathrm{r}}\right)$ at during] 2-5] sec, and the Moment of inertia varied $\left(\mathrm{J}_{1}=1.5^{*} \mathrm{~J}\right)$ at during] 6-9] sec. 

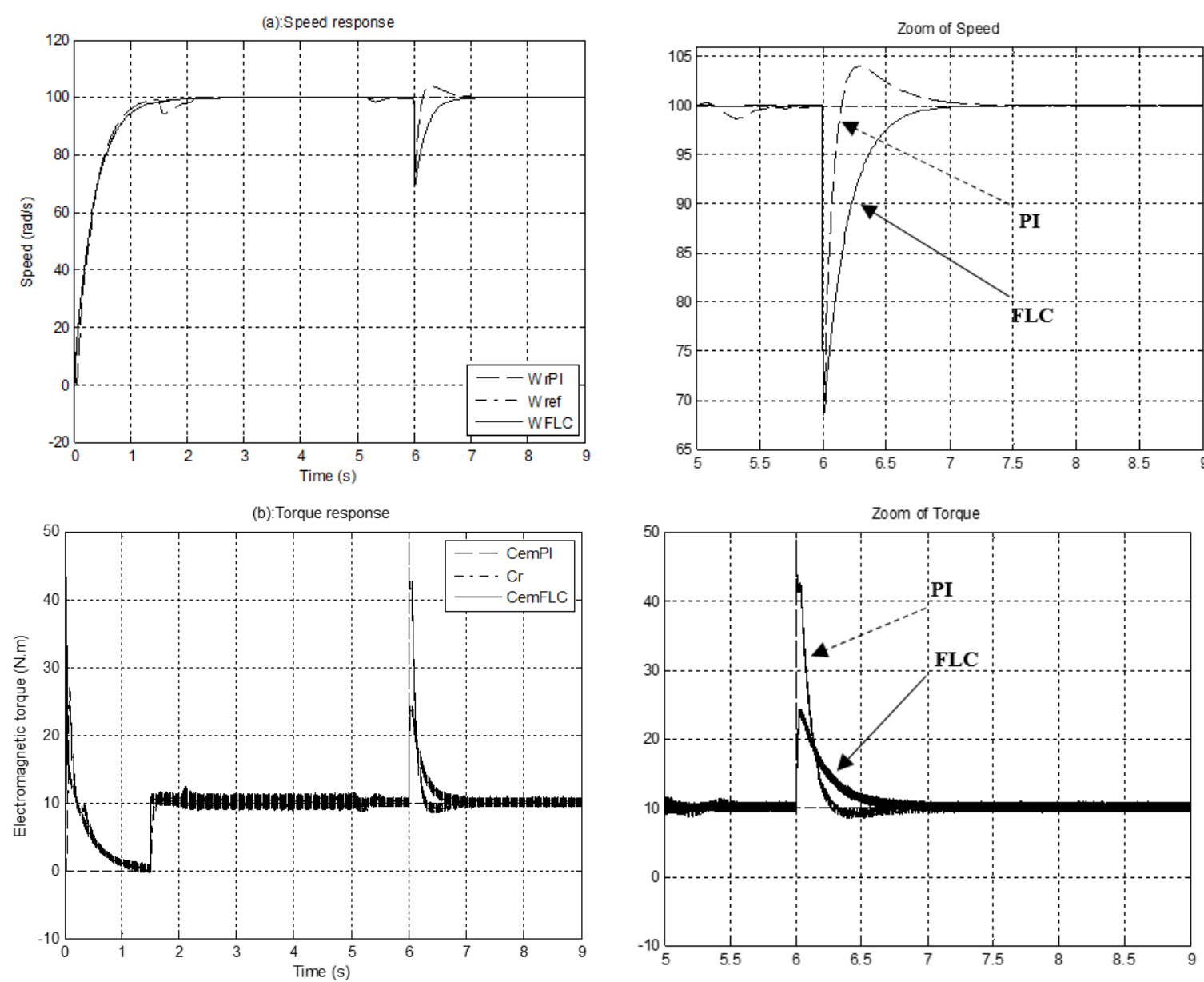

Figure 8. Speed and torque characteristic of an (DFOC) with PI and FLC controllers, at parametric variations (rotor resistance $\left(\mathrm{R}_{\mathrm{r} 1}=1.5 * \mathrm{R}_{\mathrm{r}}\right)$, moment of inertia $\left.\left(\mathrm{J}_{1}=1.5 * \mathrm{~J}\right)\right)$.

Figure 6 shows that responses for DFOC of DSIM using the proposed PI and FLC, We note that when the motor starts, the speed reaches its reference speed $(100 \mathrm{rad} / \mathrm{s})$, the mechanical torque increases to reach the peak value $(44 \mathrm{~N} . \mathrm{m})$ and falls down to be close zero value because the motor running with no load. At during [2-5] sec we changed the value of load torque to $\mathrm{C}_{\mathrm{r}}=10 \mathrm{~N} . \mathrm{m}$, the motor output torque will increase to cover this load. The harmonics magnitude of electromagnetic torque produced by the FLC is inferior than produced by PI, Figure.6 (b).and the change in command speed is realized as following: ([0-6] sec $\left.\omega_{\mathrm{r}}{ }^{*}=100 \mathrm{rad} / \mathrm{s}\right)$ and (]6-9] $\left.\mathrm{sec} \omega_{\mathrm{r}}{ }^{*}=30 \mathrm{rad} / \mathrm{s}\right)$. The rotor speed obtained by the FLC track very quickly the desired reference speed than the one obtained with PI, Figure. 6 (a). This test has for object the study of controller behaviors in pursuit and in regulation.

It is clear from Figure 7 the decoupling control of torque and rotor flux can be achieved in terms of d-axis and q-axis magnetizing current, respectively. The direct rotor field ( $\Phi \mathrm{rd})$ follows the reference value $(1 \mathrm{~Wb})$ and the quadrature component ( $\Phi \mathrm{rq})$ is null. Thus, the orientation is assured, Figure 7(b).

Figure. 8 shows the second test concerns a presents the behavior of FLC and PI speed control when the parameter variations (rotor resistance, moment of inertia), the change in the Rotor resistance (Rotor resistance $\left(R_{r 1}\right)$ ) is realized as follows: ([2-5] sec $\left.\mathrm{R}_{\mathrm{rl}}=1.5^{*} \mathrm{R}_{\mathrm{r}}\right)$, and the moment of inertia is varied (moment of inertia $\left(\mathrm{J}_{1}\right)$ ) at during (] 6-9] sec $\mathrm{J}_{1}=1.5^{*} \mathrm{~J}$ ). Influence of the parameter variations on the electromagnetic torque and speed response is shown in Figure.8 (a), (b).
The PI and a FLC controller is tuned at rated conditions in order to make a fair comparison between the speed control of the DSIM-DFOC by a PI and a FLC is presented in all figures.

In the present study, an integral squared error (ISE), integral absolute error (IAE) and integral time-weighted absolute error (ITAE) are utilized to judge the performance of the controllers. $I S E, I A E$ and ITAE criterion is widely adopted to evaluate the dynamic performance of the control system. The index ISE, $I A E$ and ITAE is expressed as follows [19-20]:

$$
\begin{aligned}
& I S E=\int_{0}^{T} e^{2}(t) d t \\
& I A E=\int_{0}^{T}|e(t)| d t \\
& I T A E=\int_{0}^{T} t|e(t)| d t
\end{aligned}
$$

Table 2. Quantitative comparison between the proposed FLC and PI controllers

\begin{tabular}{llll}
\hline $\begin{array}{l}\text { Controllers } \\
\text { Index }\end{array}$ & PI & FLC \\
\hline & Speed & 39.38 & 0.6798 \\
ISE & Flux & 0.1987 & 0.1971 \\
& Speed & 10.5 & 0.6189 \\
IAE & Flux & 0.4251 & 0.4117 \\
& Speed & 34.21 & 1.762 \\
ITAE & Flux & 0.2381 & 0.2142 \\
\hline
\end{tabular}

For quantitative comparison between two methods, ISE, $I A E$ and ITAE are used as the criterion. Table. 2 shows the ISE, 
IAE and ITAE values of the simulation results using the PI controller and the proposed FLC Controller (Test1). Actually these performances index are obtained at the end of the simulation time $(\mathrm{t}=9 \mathrm{sec})$ with a sampling period $\mathrm{h}=1 * \mathrm{e}-5$.

This comparison shows clearly that the FLC gives good performances and it's more robust than PI.

\section{CONCLUSION}

In this study, the performances of speed FLC and PI controllers for direct field oriented control of DSIM are presented, has been described. The system was analyzed and designed. The performances were studied extensively by simulation to validate the theoretical concept. To avoid the complexity of the FLC and the decrease of its precision.

The robustness tests show too that the FLC is more robust than the PI controller with the speed and torque and parameter variations. The FLC is a useful tool for replacing the PI in all applications (high power variable-speed multi-phase induction machine drives) requiring a good performance and a great robustness and reach high quality in control of non linear systems.

The simulation study indicates clearly the superior performance of FLC, the comparison done in this work shows that the limits of this type of PI controller can have negative effects on the performance of the DSIM.

\section{REFERENCES}

[1] Hadiouche D, Razik H, Rezzoug A. (2004). On the modeling and design of dual stator windings to minimize circulating harmonic currents for VSI Fed AC machines. IEEE Transactions on Industry Applications 40(2): 506515. https://doi.org/10.1109/TIA.2004.824511

[2] Tir Z, Soufi Y, Hashemnia MN, Malik OP, Marouani K. (2016). Fuzzy logic field oriented control of double star induction motor drive. Electrical Engineering 5: 1-9. https://doi.org/10.1007/s00202- 016-0377-2

[3] Tir Z., Malik OP, Eltamaly AM. (2016). Fuzzy logic based speed control of indirect field oriented controlled double star induction motors connected in parallel to a single six-phase inverter supply. Electric Power Systems Research 134: 126-133. https://doi.org/10.1007/s00202016-0377-2

[4] Hadiouche D, Razik H, Rezzoug A. (2000). Study and simulation of space vector PWM control of double-star induction motors. In: Proc. of the VII IEEE International Power Electronics Congress, Acapulco, Mexico: 42-47. https://doi.org/10.1109/CIEP.2000.891389

[5] Radhwane S. (2014). Direct vector control scheme for a dual stator induction machine (DSIM) using fuzzy logic controller. Journal of Advanced Research in Science and Technology 1N1: 28-38.

[6] Amimeur H, Abdessemed R, Aouzellag D, Merabet E, Hamoudi F. (2008). Modeling and analysis of dual-stator windings self-excited induction generator. Journal of Electrical Engineering, JEE 8(3).

[7] Ghalem B, Bendiabdellah A. (2010). Six-phase matrix converter fed double star induction motor. Acta Polytechnica Hungarica 7(3).

[8] Radhwane S, et al. (2012). Indirect rotor field-oriented control (IRFOC) of a dual star induction machine (DSIM) using a fuzzy controller. Acta Polytechnica Hungarica 9(4).

[9] Hadiouche D. (2001). Contribution à l'étude de la machine asynchrone double étoile modélisation, Alimentation et structur. Thèse de doctorat, Université Henri Poincaré, Nancy-1.

[10] Gabriel R, Leonhard W, Nord CJ. (1980). Field-oriented control of a standard ac motor using microprocessors. IEEE Transactions on Industrial Applications 16(2). https://doi.org/10.1109/tia.1980.4503770

[11] Brod DM, Novotny DW. (1985). Current control of VSIPWM inverters. IEEE Transactions on Industry Applications https://doi.org/10.1109/tia.1985.349711

[12] Lekhchine S, Bahi T, Soufi Y. (2014). Indirect rotor field oriented control based on fuzzy logic controlled double star induction machine. International Journal of Electrical Power \& Energy Systems 57: 206-211. https://doi.org/10.1016/j.ijepes.2013.11.053

[13] Khouidmi H, Massoum A, Meroufel A. (2011). Dual star induction motor drive: Modeling, supplying and control. International journal of electrical and power engineering 5(1): 28-34.

[14] Nasri A, Hazzab A, Bousserhane IK. (2010). Fuzzy logic speed control stability improvement of lightweight electric vehicle drive. Journal of Electrical Engineering and Technology: 129-13.

[15] Belhamdi S, Goléa A. (2011). Sliding mode control of asynchronous machine presenting defective rotor bars. AMSE Journals, Series Advances C 66(1-2): 39-49.

[16] Aissaoui A, Abid M, Abid H, Tahour A, Zeblah A. (2007). A fuzzy logic controller for synchronous machine. Journal of Electrical Engineering 58(5): 285290.

[17] Meliani B, Meroufel A, Khouidmi H. (2012). Fuzzy gain scheduling of pi controller for dual star induction machine fed by a matrix converter. Carpathian Journal of Electronic and Computer Engineering 5(6): 77-82.

[18] Belhamdi S, Goléa A. (2013). Fuzzy logic control of asynchronous machine presenting defective rotor bars. AMSE Journals, Series Advances C 68(2): 54-63.

[19] Belhamdi S, Goléa A. (2015). Direct torque control for induction motor with broken bars using fuzzy logic Type-2". AMSE Journals, Series Advances C 70(1-2): $15-28$.

[20] Castillo O, Melin AP. (2008). Type-2 fuzzy logic, Theory and applications 223, Springer-Verlag, Berlin, 2008. https://doi.org/10.1007/978-3-540-76284-3

\section{NOMENCLATURE}

$\begin{array}{lc}\text { DSIM } & \text { Doubly Star Induction Motor } \\ \text { FOC } & \text { Field Oriented Control } \\ \text { IFOC } & \text { Indirect Field Oriented Control } \\ \text { DFOC } & \text { Direct Field Oriented Control } \\ \text { PI } & \text { Proportional and Integral } \\ \text { FLC } & \text { Fuzzy Logic Controller } \\ \Omega_{\mathrm{r}} & \text { The rotor angular speed } \\ \mathrm{C}_{\mathrm{em}} & \text { Electromagnetic torque } \\ \mathrm{K}_{\mathrm{f}} & \text { Friction coefficient } \\ \mathrm{J} & \text { Moment of inertia } \\ \mathrm{C}_{\mathrm{r}} & \text { Load torque }\end{array}$



$\theta_{\mathrm{s}} \quad$ Angle between stator and rotor flux
$\mathrm{P} \quad$ Number of pole pairs
$\omega_{\mathrm{sr}}{ }^{*} \quad$ Slip speed reference

\section{APPENDIX}

Table 3. DSIM parameters (Radhwane S. et al 2012)

\begin{tabular}{ll}
\hline DSIM Mechanical Power & $4.5 \mathrm{~kW}$ \\
Nominal voltage & $220 \mathrm{~V}$ \\
Frequency & $50 \mathrm{~Hz}$ \\
Pole pair number & 1 \\
Stators 1,2 resistances & $3.72 \Omega$ \\
Rotor resistance & $2.12 \Omega$ \\
Stators 1,2 self inductances & $0.022 \mathrm{H}$ \\
Rotor inductance & $0.006 \mathrm{H}$ \\
Mutual inductance & $0.3672 \mathrm{H}$ \\
Moment of inertia & $0.0625 \mathrm{Nms} / / \mathrm{rad}$ \\
Friction coefficient & $0.001 \mathrm{Nms} / \mathrm{rad}$ \\
\hline
\end{tabular}

